\title{
Recent development in preparation of food packaging films using biopolymers
}

\author{
${ }^{1}$ Suresh, S., ${ }^{2}$ Pushparaj, C. and ${ }^{1, *}$ Subramani, R. \\ ${ }^{1}$ Department of Food Processing Technology and Management, PSGR Krishnammal College for Women, \\ Coimbatore, Tamil Nadu, India \\ ${ }^{2}$ Department of Zoology, PSGR Krishnammal College for Women, Coimbatore, Tamil Nadu, India
}

\author{
Article history: \\ Received: 1 February 2021 \\ Received in revised form: 19 \\ March 2021 \\ Accepted: 22 May 2021 \\ Available Online: 7 \\ November 2021
}

Keywords:

Biopolymers,

Edible films,

Food packaging,

Preservation,

Shelf life

DOI:

https://doi.org/10.26656/fr.2017.5(6).082

\begin{abstract}
In the past decades, most materials used in the food packaging industry are nonbiodegradable materials that pose increased environmental concerns and sustainability issues. Hence, polymer-based biodegradable materials and edible films have been developed to increase the shelf life of food products. Especially, biopolymer-based nanomaterials are engineered with multifunctional characteristics because of their size, surface area, shelf life, thermal stability, and mechanical and barrier strength. These materials display enriched properties of biodegradability, antimicrobial activity, and biocompatibility and may have the possibility to replace plastic materials in future. Thus, this review offers a brief overview of the classification of biopolymers, key parameters that are important in food packaging films (including the role of plasticizers, cross-linkers, $\mathrm{pH}$, temperature, and relative humidity), and recent applications of novel biopolymer nanocomposite materials used in the food industries.
\end{abstract}

\section{Introduction}

Despite various initiatives from international and national governing bodies concerning the usage of plastic, it is impossible to avoid plastic in day-to-day activities because of high demands in rapid urbanization (Valdés et al., 2014; Axelsson et al., 2017; Geueke et al., 2018). The superior properties of the plastic including water resistance; optical, mechanical, and barrier strength; transparency; chemical inertness; lightweight; and resistivity towards heat make them suitable for food packaging (Valdés et al., 2014). Polyethylene (PE) is the first polymer used for food packaging to make cups, squeeze bottles, extrusion coating for paper boards (Geueke et al., 2018). Later, various thermoplastic-based polymers were developed including polyvinyl chloride (PVC), polyethylene terephthalate (PET), polypropylene (PP), styrene butadiene (SB), and acrylonitrile butadiene styrene (ABS) materials for food packaging. Each individual polymer has unique characteristics in a certain way. PE is a heat-sealing polymer that can produce a tough and thick film with a better barrier to moisture (Coles et al., 2003). PP is prepared using a Ziegler-Natta catalyst giving a harder and denser polymer with high transparency and flexibility (Marsh and Bugusu 2007). PP is widely used for lamination, printing, and coating. PET is a condensation polymer showing higher heat resistance and mechanical strength than other nondegradable polymers (Kirwan et al., 2011). PET is an alternate for PVC, and it is an emerging polymer used to prepare carbonated soft drinks bottles, packaged drinking water bottles, and edible oil containers (Geueke et al., 2018).

Despite having these superior advantages, it lacks other important properties like degradability, having a low melting rate, and a low recycling rate. In addition, plastic materials have toxicity and high economic value to dispose of the waste, which make them unsuitable for various applications, particularly in food industries (Siracusa et al., 2008). As an alternative, biopolymers have been successfully exploited by the food industries in recent years. These biopolymers or polymeric biomolecules are naturally produced or synthesized from renewable materials (starch, proteins, natural fat, oil, and sugar) (Nešić al., 2020). These prepared materials are biodegradable, biocompatible, non-toxic, chemically inert, and cost-effective, depending on the composition (Zhong et al., 2019). In addition, a vast amount of money can be saved by converting natural-based polymer waste into usable biodegradable materials (Marsh and Bugusu 2007).

Bionanocomposites or biopolymer blends are 
prepared by using plasticizer, compatibilizer, or additives to the polymers (Vieira et al., 2011). As an example, starch/MMT clay nanocomposites material were prepared to enhance the barrier and mechanical properties of the biodegradable film by melt extrusion method (Tang et al., 2008). Various types of NPs were incorporated into the biopolymers (chitosan, alginate, agar, carrageenan and CMC-carboxy methylcellulose) to develop antimicrobial nanocomposite films for active packaging (Kanmani et al., 2014). In addition, edible films are also prepared by making a thin layer that is used to wrap the food surface with biopolymeric materials. This is done by applying coating (by using methods like dipping and spraying) which forms a layer directly on the food surface (Zhong et al., 2019). Edible films can be used to produce a soluble package for premixed food ingredients or additives that acts as a separate layer of individual food portions. Therefore, the preparation of novel Nano biopolymer-based materials for food industry applications and their functional properties are key to overcome the usage of nonbiodegradable materials.

\section{Classification of biopolymers}

Biopolymers are classified based on the applications or origin of resources or chemical or physical properties. Based on the origin of resources, biopolymers are classified as vegetable origin (lignin, starch, or cellulose), animal origin (chitin or collagen), from microbe sources (polyhydroxy butyrate or polylactic acid), and from bio-based monomers (poly-ecaprolactone and polyglycolic acid) by Błedzki et al (2012). Karthik et al. (2009) have classified the biopolymers into four types: agro-polymers (polysaccharides and proteins), microorganism extracts (polyhydroxyalkanoates), bio conventionally synthesized monomers (polylactides), and petrochemical products (polycaprolactone, homopolyester, and aliphatic and aromatic copolyester which are synthetically synthesized monomers). Based on degradation, it was classified into two major categories: natural and synthetic biopolymers. Natural biopolymers are proteins, polysaccharides, and polynucleotides, whereas polylactic acids, polycaprolactone, polyhydroxy butyrate, are synthetic biopolymers, as shown in Figure 1 (Zia et al., 2017). A detailed summary of polymer types and their sources, properties, and their applications with examples are shown in the Table 1.

\section{Parameters that play role in food packaging applications}

\subsection{Effect of plasticizer}

A plasticizer is an additive used to increase the elasticity of the film. Plasticizers are an important class of nonvolatile compounds with molecular weight ranging from 300 to $600 \mathrm{kDa}$ (Sothornvit et al., 2005; Vieira et al., 2011; Muhammed et al., 2015; Suderman et al., 2018). The role of a plasticizer is to change the physical and/or chemical properties of materials when added. This leads to improving the mechanical properties (flexibility and tensile strength), barrier properties (water Vapour permeability and oxygen permeability), and optical properties (glossiness and opacity) (Vieira et al., 2011). Currently, numerous plasticizers are being used in various applications. Water, glycerol, sorbitol, mannitol, sucrose, and polyethylene glycol are the most commonly used plasticizers in the food industry. These plasticizers help change the three-dimensional molecular structure of

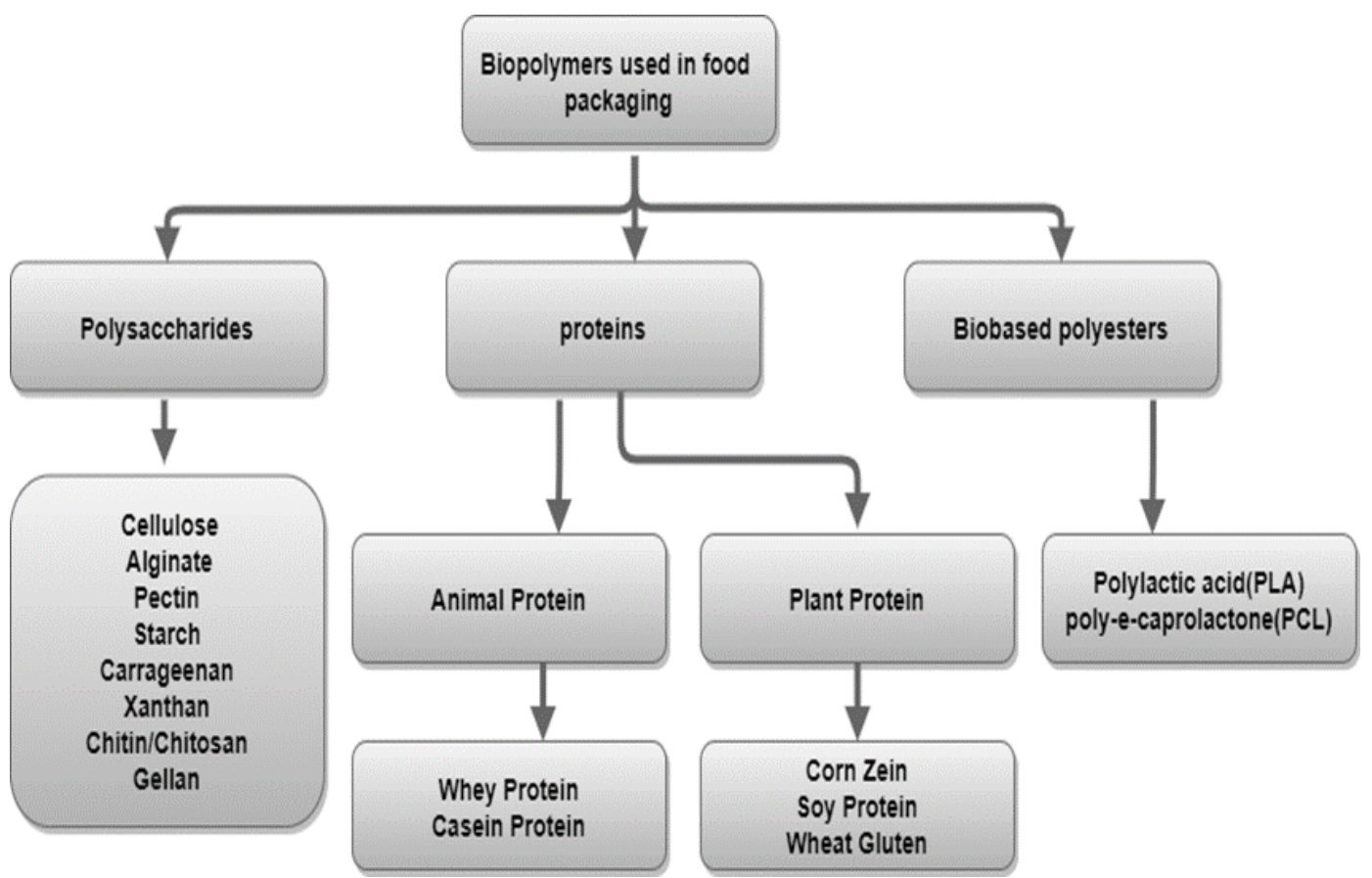

Figure 1. Schematic representation of the classification of the biopolymers. 
Table 1. A detailed summary of polymer types and their sources, properties, and their applications with examples.

\begin{tabular}{|c|c|c|c|}
\hline Biopolymers & Sources & Properties & Selected references \\
\hline Cellulose & $\begin{array}{l}\text { Most abundant biopolymer made of sugar } \\
\text { monomer unit, extracted from plant fiber. It is a } \\
\text { homo polysaccharide composed of }(\beta-1,4) \text {-linked } \\
\text { glucopyranose units. }\end{array}$ & $\begin{array}{l}\text { Light weight, durability, high } \\
\text { melting point, low-permeability }\end{array}$ & $\begin{array}{l}\text { Chen (2014); Padrão et } \\
\text { al. (2016) }\end{array}$ \\
\hline Alginate & $\begin{array}{l}\text { Extracted from brown algae by treatment with } \\
\text { aqueous alkali solutions. Calcium and sodium } \\
\text { salts of alginic acid are known as alginates. }\end{array}$ & $\begin{array}{l}\text { Anti-microbial, tensile strength, } \\
\text { Thermal stability. }\end{array}$ & $\begin{array}{l}\text { Lee and Mooney } \\
\text { (2012); Adbollahi et al. } \\
\text { (2013); Yang et al. } \\
\text { (2019) }\end{array}$ \\
\hline Pectin & $\begin{array}{l}\text { Pectin is rich in apple, sugar-beet pulp and in } \\
\text { citrus peels and different plant sources. It is a } \\
\text { complex anionic polysaccharide having } \beta-1,4- \\
\text { linked D-galacturonic acid. }\end{array}$ & $\begin{array}{l}\text { Biocompatibility in nature, ease } \\
\text { of gelling, stabilizing ability, } \\
\text { thickening and emulsifier. }\end{array}$ & $\begin{array}{l}\text { Marquez et al. (2017); } \\
\text { Ferrari et al. }(2013)\end{array}$ \\
\hline Starch & $\begin{array}{l}\text { Hydrocolloid polymer found in rice, corn, wheat, } \\
\text { potatoes and cassava. }\end{array}$ & $\begin{array}{l}\text { Hydrophilic nature, gel forming } \\
\text { property, used as a thickener, } \\
\text { colloidal, stabilizer, and water } \\
\text { retention agent. }\end{array}$ & $\begin{array}{l}\text { Ortega-Toro et al. } \\
\text { (2017) }\end{array}$ \\
\hline Carrageenan & $\begin{array}{l}\text { Carrageenan is derived from red seaweed, forms } \\
\text { highly viscous aqueous solutions. It is an anionic } \\
\text { linear sulphated polysaccharide joined by } \\
\text { glycosidic linkage. }\end{array}$ & $\begin{array}{l}\text { Additive to preserve food, } \\
\text { thickener and emulsifier. }\end{array}$ & $\begin{array}{l}\text { Seol et al. (2009); } \\
\text { Shojaee et al. (2013) }\end{array}$ \\
\hline Xanthan & $\begin{array}{l}\text { Xanthan gum produced by the bacterium } \\
\text { Xanthomonas campestris, is soluble in cold and } \\
\text { hot water. The polymer backbone is made up of } \\
(1 \rightarrow 4) \text {-linked } \beta \text {-D-glucopyranosyl units } \\
\text { (identical to cellulose). }\end{array}$ & $\begin{array}{l}\text { Thickening, emulsifying, } \\
\text { gelling and stabilizing agent. }\end{array}$ & $\begin{array}{l}\text { García-Ochoa et al. } \\
(2000) ; \text { Sharma and Rao } \\
(2015) ; \text { Kim et al. } \\
(2012)\end{array}$ \\
\hline $\begin{array}{l}\text { Chitin/ } \\
\text { Chitosan }\end{array}$ & $\begin{array}{l}\text { Chitin is the second most used polysaccharide } \\
\text { after cellulose. Chitin is a white, hard } \\
\text { nitrogenous polysaccharide found in the internal } \\
\text { structure of invertebrates and cell walls of fungi. }\end{array}$ & $\begin{array}{l}\text { Anti-microbial, anti-fungal and } \\
\text { anti-oxidant properties. }\end{array}$ & $\begin{array}{l}\text { Harish Prashanth et al. } \\
\text { (2007); Cheba et al. } \\
\text { (2015); Zhang et al. } \\
\text { (2017) }\end{array}$ \\
\hline Gellan & $\begin{array}{l}\text { Anionic polysaccharides secreted and extracted } \\
\text { from the bacterium Sphingomonas paucimobilis } \\
\text { by aerobic fermentation. }\end{array}$ & $\begin{array}{l}\text { Stabilizer, gelling, film-forming } \\
\text { and encapsulation agent. }\end{array}$ & $\begin{array}{l}\text { Xiao et al. }(2011) \\
\text { Moreira } \text { et al. }(2015) \\
\text { Wei et al. }(2017)\end{array}$ \\
\hline $\begin{array}{l}\text { Whey } \\
\text { protein }\end{array}$ & $\begin{array}{l}\text { Whey protein is obtained from milk. Cow milk } \\
\text { contains } 80 \% \text { casein and } 20 \% \text { whey protein } \\
\text { which is a byproduct in cheese production. }\end{array}$ & $\begin{array}{l}\text { High binding ability, moderate } \\
\text { permeability and plasticizing } \\
\text { capacity }\end{array}$ & $\begin{array}{l}\text { Javanmard (2008); } \\
\text { Thawien (2012). }\end{array}$ \\
\hline $\begin{array}{l}\text { Casein } \\
\text { Protein }\end{array}$ & $\begin{array}{l}\text { Casein Protein is found in Mammalian milk and } \\
\text { the production of cheese. }\end{array}$ & $\begin{array}{l}\text { High tensile strength and good } \\
\text { oxygen barrier property }\end{array}$ & $\begin{array}{l}\text { Avena-Bustillos, et al. } \\
\text { (1994); Picchio et al. } \\
\text { (2018). }\end{array}$ \\
\hline Zein & $\begin{array}{l}\text { Zein is found in corn (Maize). It comes under the } \\
\text { class of prolamine protein. }\end{array}$ & $\begin{array}{l}\text { Odorless, water-insoluble and } \\
\text { hydrophobic in nature, water- } \\
\text { resistant capability and ability } \\
\text { to remove moisture, it has been } \\
\text { extensively used for making } \\
\text { edible films. }\end{array}$ & $\begin{array}{l}\text { Luecha et al. (2010); } \\
\text { Ozcalik and } \\
\text { Tihminlioglu (2013). }\end{array}$ \\
\hline Soy protein & $\begin{array}{l}\text { One of the most versatile proteins found in } \\
\text { soybean and has all the essential amino acids. } \\
\text { Soy protein exists in three forms which are soy } \\
\text { flour (SF), soy protein concentrate (SPC) and } \\
\text { soy protein isolates (SPI) }\end{array}$ & $\begin{array}{l}\text { Hydrating capacity, solubility, } \\
\text { colloidal stability, gelation, } \\
\text { emulsification, foaming and } \\
\text { adhesion/cohesion }\end{array}$ & $\begin{array}{l}\text { Kinsella (1979); Singh } \\
\text { et al. (2008); Chinma et } \\
\text { al. (2012). }\end{array}$ \\
\hline $\begin{array}{l}\text { Wheat } \\
\text { gluten }\end{array}$ & $\begin{array}{l}\text { It belongs to the prolamine protein group. Wheat } \\
\text { gluten is the by-product of the isolation of starch } \\
\text { in wheat flour. Industrially gluten is produced } \\
\text { from wheat flour by the drying process and wet }\end{array}$ & $\begin{array}{l}\text { Gel forming ability, water- } \\
\text { holding capacity, elastic nature } \\
\text { and thermosetting properties. }\end{array}$ & $\begin{array}{l}\text { Day (2011); Heralp } \\
\text { (1993) }\end{array}$ \\
\hline $\begin{array}{l}\text { Poly Lactic } \\
\text { acid (PLA) }\end{array}$ & $\begin{array}{l}\text { It is obtained by ring-opening polymerization of } \\
\text { lactides or from the condensation of lactic acid. } \\
\text { PLA exist in two enantiomeric forms D-PLA and } \\
\text { L-PLA. }\end{array}$ & $\begin{array}{l}\text { High strength, oil and grease } \\
\text { resistance, thermoplastic nature, } \\
\text { hydrophobicity, flexibility, } \\
\text { toughness and biocompatibility. }\end{array}$ & $\begin{array}{l}\text { Ljungberg and Wessle } \\
\text { (2005); Sébastien et al. } \\
\text { (2006); Muller et al. } \\
\text { (2017). }\end{array}$ \\
\hline
\end{tabular}


Table 1 (Cont.). A detailed summary of polymer types and their sources, properties, and their applications with examples.

\begin{tabular}{llll}
\hline Biopolymers & \multicolumn{1}{c}{ Sources } & \multicolumn{1}{c}{ Properties } & \multicolumn{1}{c}{ Selected references } \\
\hline PolyCapro & Obtained by ring-opening polymerization of & Used as an additive or a & Yun et al. (1966); \\
Lactone & caprotalctone extracted from sugar cane. & plasticizer to food coating due & Joseph et al. $(2011) ;$ \\
(PCL) & & to the non-toxic nature, & Sogut and Seydim \\
& & flexibility, resistivity toward & $(2018)$.
\end{tabular}

polymers resulting in a change in the mobility of the polymer chain and also increasing extensibility to the chain (Sanyang et al., 2015). For instance, increasing the glycerol content in cassava starch film solution gives more flexibility, less stiffness, and rigid nature to the film because of the interaction between the adjacent biopolymer chains in the film matrix (Souza et al., 2012). Gelatin film was made by using different plasticizers involving glycerol, sorbitol, and polyethylene glycol; however, gelatin-glycerol plasticization showed good mechanical strength compared with other compositions. The main reason is that the penetration of a small amount of glycerol into the polymer chain loosens the hydrogen bonding and creates free volume between the film matrix, thus increasing the flexibility and extensibility of the film (Suderman et al., 2018). It can be crystalline solid or amorphous (glassy or rubbery) in nature. Glass transition $\left(T_{g}\right)$ theory can be utilized to explain plasticizer effects on mechanical and permeability properties. Glass transition occurs when polymer structures changes from brittle glass to highly viscous or rubbery solid state. An increase in plasticizer content leads to a decrease in glass transition temperature. If $\mathrm{T}_{\mathrm{g}}$ is decreased, the brittleness of the film increases because of the polymer-plasticizer interactions (Bhandari et al., 2016). In the sugar palm starch (SPS) film, different plasticizers were used to increase the mechanical and barrier properties of the film due to plasticizers diminishing the strong intramolecular attraction between the starch chains and promoting the formation of hydrogen (Sanyang et al., 2015).

Barrier properties are essential in the food packaging system for commercial manufacturing to extend the shelf life and quality of food products by controlling the permeability of gases (like water Vapour, $\mathrm{CO}_{2}$, and $\mathrm{O}_{2}$ ) and aroma transport. In general, gas permeability for a film highly depends on the nature of gas, the structure of a material, relative humidity, and processing temperature. These gases are involved in degradation processes (rancidity, enzymatic browning) that change the internal space of the packaging film and its environment. This leads to economic and commercial disadvantages of food packaging applications; hence, controlling the permeability of the gases in packaging materials is particularly important (Siracusa et al., 2012). Film prepared with corn zein, wheat gluten, and cellulose (methyl and hexamethyl cellulose) showed lower oxygen and $\mathrm{CO}_{2}$ permeability than commercial plastic film. Adding Myvacet 7-OOT, as a plasticizer, decreased the permeability of hexamethyl cellulose (HPC) to approximately $43.2 \%$ (Park et al., 1995). To increase the physicochemical properties of fish gelatin film, a composite was made by using fish gelatin and chitosan at different concentrations, resulting in a reduction in water vapour permeability (WVP) and solubility. Chitosan limits the amount of water Vapour passing through the film membrane, thus lowering the WVP (Fakhreddin et al., 2013).

\subsection{Effect of cross-linkers}

Cross-linkers are used to improve the water resistance, rigidity, barrier and mechanical strength, and thermostability. The most commonly used cross-linkers are glutaraldehyde, citric acid, glyceraldehyde, transglutaminase, formaldehyde, and lactic acid. Crosslinkers are particularly suitable for proteins when compared with other biopolymers. Cross-linkers increase the intermolecular hydrogen bonding by generating the strong covalent bond leading to three-dimensional networks (Liang et al., 2019). Introducing cross-linking agent to the biopolymer is completely dependent on the structural arrangement of biopolymer, molecular weight, and compatibility of cross-linker (Garavand et al., 2017). Cross-linking effect of citric acid on pea starch biocomposite film has modified the storage modulus, tensile strength, and glass transition temperature (Ma et al., 2009).

\subsection{Effect of $p H$, temperature, time, and relative humidity}

\subsection{1 $\mathrm{pH}$}

Depending on the $\mathrm{pH}$, gel formation for a film differs in its functional properties because of the presence of hydrogen bonding, hydrophobic interaction, electrostatic interaction, and disulphide linkage of protein. The effect of $\mathrm{pH}$ on surimi-gelatin composite film shows that there was a change in the mechanical properties when $\mathrm{pH}$ was adjusted to an acidic or alkaline condition. High and low Elongation at Break (EAB) was observed at $\mathrm{pH} 3$ and $\mathrm{pH} 10$ respectively and vice versa for Tensile Strength (TS); however, both EAB and TS were lowest at $\mathrm{pH}$ 7. This is mainly due to the protein unfolding and interactions when the $\mathrm{pH}$ of the solutions are changed (Tao et al., 2015). In preparation of biodegradable food packaging film using fish (white 
mouth croaker) protein, $\mathrm{pH}$ can vary from 2 to 10 . At $\mathrm{pH}$ 2 , the film has greater elasticity during gelation and maintains the mechanical strength in comparison to $\mathrm{pH}$ 10 due to the conformational changes of the protein structures (Romani et al., 2018). In gelatin film incorporated with corn oil, tensile strength (TS) value decreased when $\mathrm{pH}$ increased; under neutral $\mathrm{pH}$, TS increased. The highest value of TS was obtained at $\mathrm{pH}$ 9.5 because of the high crystallinity and gel-forming ability of gelatin (Bourtoom et al., 2006).

\subsubsection{Temperature and time}

Temperature and time are major important factors to improve the quality and shelf life of food packaging film. The solubility of whey protein isolate (WPI) was affected by heating time and temperature. Heating at a higher temperature can unfold the protein, resulting in protein-protein cross-linking interaction by exposing - $\mathrm{SH}$ groups that enable the formation of covalent intermolecular disulfide bonds, which are accountable for film water insolubility (Perez-Gago and Krochta 2001). In cassava starch and soy protein concentrate (SPC)-based edible films, tensile strength, elastic modulus, and water Vapour permeability of edible films increased with increasing the temperature because of the free movement of the polymer segment, film-forming formulation and drying process (Chinma et al., 2015). In the preparation of Potato starch film; there was an increase in Tensile strength and microstructure properties due to the effect of mixing temperature $\left(80^{\circ} \mathrm{C}, 85^{\circ} \mathrm{C}\right)$. The obtained SEM images were confirmed that the development of microstructures during gelation resulting in the formation of smooth and homogenous film structure (Zakaria et al., 2018).

\subsubsection{Relative humidity}

In the food packaging industry, maintaining the relative humidity $(\mathrm{RH})$ for a film is an essential factor for its mechanical and barrier properties. Compared with plastic, biopolymers can modify their mechanical and barrier properties in high moisture conditions, especially in fresh-cut fruits and vegetables. Generally, films having high $\mathrm{RH}$ have higher water content than films containing lower RH. For example, Composite film made by using chitosan, fish gelatin, glycerol, and transglutaminase were highly homogenous and flexible because of the effect of relative humidity on tensile strength and elongation. Tensile strength and elongation were increased when RH is increased. This is due to the hydrophilic nature of gelatin and cross-linking ability of glycerol (Alvarado et al., 2015). Protein (corn zein and wheat gluten) and cellulose-based films (methylcellulose (MC) and hydroxypropyl cellulose) were studies to test the Tensile strength of the film as a function of $\mathrm{RH}$ and
T. An increase in the RH and T resulting in a decrease in the TS due to the amount of water absorbed by the hydrophilic films (Gennadios et al., 1993).

\section{Biopolymers applications in selected food industries}

Food packaging technology is one of the vast developing fields because of the increasing demands for packaged food products. Particularly, edible food packaging may increase the economic and nutritional value of food products. Packaging is an essential bridge between the manufacture and consumer to increase the availability of quality food products, hygiene, and safety. Therefore, biopolymers can provide the best solution to enhance the quality and prolonged shelf life of food products. The applications of the biopolymers are discussed for five major food industries that are responsible for producing and selling millions of products in day-to-day life.

\subsection{Fruits and vegetable industries}

Fresh cut fruits and vegetables are generally perishable materials when in contact with open air, resulting in loss of sensory properties, loss of tissue texture, and degradation of the cell membrane. When fruits or vegetables are peeled or cut, certain enzymes are exposed to air and oxidized, leading to the browning of the surface of fruits or vegetables. In addition, the growth of microorganisms such as bacteria (e.g., Lactobacillus spp. and Escherichia coli), yeasts (e.g., Saccharomyces), and moulds (e.g., Rhizopus) spoils the agricultural products; hence, storage and food packaging are the essential tools to increase the shelf life (Barth et al., 2009). Therefore, bio-derived polymers such as alginate, chitosan, and carrageenan were used as edible packaging materials (Abdul Khalil et al., 2018). A combination of $1.29 \%(\mathrm{w} / \mathrm{v})$ chitosan with $0.42 \%$ glycerol and $1.49 \%(\mathrm{w} / \mathrm{v})$ carrageenan with $0.03 \%$ glycerol were coated to preserve the postharvest longan fruits, and it showed minimal quality changes and quantity losses proved by the response surface methodology (RSM) test (Lin et al., 2018). The electrostatic spraying (ES) technique was applied to strawberries using natural antimicrobial agents (alginate, carvacrol, and methyl cinnamate) that reduced the microbial contamination and mould count for approximately 11 days. After 13 days of storage, EScoated strawberries showed colour retention, weight loss reduction, and firmness in the film (Peretto et al., 2017). Edible coating using aloe vera gel $(2 \%)$ with corn starch (1\%) enhanced the shelf life of ber (Zizyphus mauritiana Lamk) fruit for up to 15 days. Aloe vera gel-coated fruits showed a minimum loss in weight, maximum colour retention, and lesser loss in acid content when compared 
with uncoated fruit. In addition, aloe vera coating reduced the ascorbic acid loss and decay percentage (Mani et al., 2017).

\subsection{Meat industries}

The meat industry involves a chain of segments that can be classified as production, processing, preserving, and packaging. Microbial contamination and protein oxidation in meat leads to food-borne illness and reduces the shelf life. Therefore, meat quality and food safety are completely dependent on the packaging materials and techniques that are used. An active packaging using edible films protects the meat from moisture loss during storage in frozen conditions, reduces the rate of rancidity, and maintains the juice content of meat. Recently, a series of new packaging technologies have been developed, including edible packaging, nanomaterial packaging, and biodegradable packaging. Such packaging mainly ensures quality, prolonged shelf life, and increases the economic value of meat products (Fang et al., 2017). The incorporation of green tea extract (GTE) into potato starch films significantly improved the film mechanical properties and decreased the oxidation of packaged fresh beef and inhibited the formation of metmyoglobin (Lee et al., 2015). Chitosan and tea polyphenol solution as natural antioxidants were used to develop a film to protect cooked pork sausages against oxidation (Domínguez et al., 2018). Polysaccharides such as agar, gelatin, corn-starch, and citrus pectin were used as components of a film-forming coating to prolong the shelf life of natural semi-finished pork meat at a storage temperature of -1 to $+1^{\circ} \mathrm{C}$ for 2 days (Soletska et al., 2018).

\subsection{Dairy industries}

Milk, fermented milk, yogurt, cheese, butter, and their functional foods are the major dairy products. Dairy products play an important role in diet to maintain the nutritional functions of the human body and act as excellent sources of vitamin A, proteins, lipids, and minerals like calcium, magnesium, and phosphorous. To prevent milk products from contamination and rancidity (aroma changes) and to maintain the aesthetic appearance, various biopolymers are used by the food industries. Chitosan/whey protein composite (CWC) is an active coating used to extend the shelf life of ricotta cheese. The coating delayed the development of acidity and did not change the sensory appearance of texture and no change in $\mathrm{pH}$ over 30 days of storage period. In CWC, lactic acid bacteria and mesophilic and psychrotrophic microorganisms were lower when compared with films that were using chitosan alone (Di Pierro et al., 2011). The effect of antimicrobial activity in mozzarella cheese was evaluated by using lemon extract as an active agent and in combination with brine and sodium alginate solution. Shelf-life tests were performed at $15^{\circ} \mathrm{C}$ to monitor the cell load of spoilage and functional microorganisms during storage. The film inhibited the growth of microorganisms such as coliforms and Pseudomonas spp. and the shelf life of mozzarella cheese was increased without affecting the sensory properties (Conte et al., 2007). Minas Padrao cheeses were coated with zein-oleic acid (Z-OA) and ZOA-xanthan gum (XG) and studied storage up to 56 days. The coated cheese samples exhibited preservation of physicochemical characteristics such as chlorides, ash, protein, and acidity compared with unpackaged and plastic-packaged cheese samples. The biodegradable coating prevented the early microbiological contamination and decreased the cheese moisture loss in comparison to unpackaged samples (Youssef et al., 2017).

\subsection{Confectionery industries}

The confectionery industry is segmented into five categories, which include chocolate, sugar, gum, cereals, and flour. The major products of the confectionery industries are candy, cake, cookies, ice creams, frozen desserts, pastries, jams, and jellies. Biopolymer-based edible packaging on the confectionary products makes more desirable outer covering and extend the product's shelf life. Edible films made with Mexican lime pectic extract and lime's essential oil possessed antibacterial potential (Aldana et al., 2015). The edible film made from sago starch, various concentrations of nutmeg pectin, and glycerol showed an increase in the water vapour permeability (WVP) value of the film. Edible sago starch films can be used as a dodol packaging material due to oxidation and act as a better barrier from oxygen permeation when compared with synthetic films (Layuk et al., 2019). An edible film consisting of potato starch and invert sugars improved the quality and safety. Incorporation of sorbate potassium and citric acid additive in the film further inhibits the yeast and mould growth up to 48 days in mini panettones (Saraiva et al., 2016). Starch, gelatin, and urea combined as a plasticizer were used as an alternative edible coating for "Korivka" candies instead of traditional paper coating. The cost of the proposed edible coating was lower by $\$ 8.77$ per 1 ton of candies compared with traditional paper material (Shylga et al., 2018).

\subsection{Seafood industries}

Seafood is consumed all over the world because of its nutritional benefits. However, it is perishable in nature when compared with chicken and other meat products. Therefore, smart edible packaging is needed to avoid the loss of texture and reduce microbial growth. 
For example, hake fish is one of the largest consumed fish in Spain. To prevent fish from microbes, the composite polymer of whey protein isolate (WPI) with essential oil is used as coating with modified atmosphere packaging (MAP) resulting in enhanced quality of the fish product during storage in the refrigerator (Carrión et al., 2018). The edible coating based on ultrasound (35 $\mathrm{kHz}$ )-treated whey protein reduced the lipid oxidation in Atlantic salmon. In addition, thaw yield, drip loss in thawing, drip loss after chilled storage, and cooking loss have not influenced the fish properties when compared with fishes with untreated whey protein coatings (Rodriguez et al., 2012). Using vacuum packaging and wrapping with chitosan-based edible film, the shelf life of fresh sea bass (Dicentrarchus labrax) fillets was improved under cold storage at $4^{\circ} \mathrm{C}$ until 20 days. Growths of microorganisms (total mesophilic and total psychrophilic aerobic bacterial counts) were significantly reduced in vacuum-packaged chitosan film wrapping (Günlü and Koyun 2013).

\section{Conclusion}

The utilization of biopolymer-based packaging is an alternative for synthetic plastics to limit the environmental damages. Although synthetic plastics are economically cheaper than degradable polymer materials, an alternative strategy is required to increase the availability of biodegradable materials. Thanks to advancements in nanotechnology, several changes have been made to extend the shelf life of food products. Specifically, Nano composite-based biomaterials exhibit numerous enhanced characteristics, including barrier properties. In addition, underutilized waste by-products from food processing industries should be converted into eco-friendly, cheaper, and degradable packaging materials, which may gain more attention and acceptance to solve environmental pollution by creating wealth from waste. Toxicity, risk assessment of nanocomposites, and migration assays are needed to ensure that these enhanced packaging materials can be utilized at their maximum by food packaging industries

\section{Conflict of interest}

The authors declare that there is no conflict of interest regarding the publication of this article.

\section{Acknowledgments}

This research was fully financially supported by Start-up Research Grant (SRG), Science and Engineering Research Board (SERB), grant no SRG/2019/001179, Department of Science and Technology (DST), Government of India.

\section{References}

Abdollahi, M., Alboofetileh, M., Rezaei, M. and Behrooz, R. (2013). Comparing physico-mechanical and thermal properties of alginate nanocomposite films reinforced with organic and/or inorganic nanofillers. Food Hydrocolloids, 32(2), 416-424. https://doi.org/10.1016/j.foodhyd.2013.02.006

Abdul Khalil, H.P.S., Banerjee, A., Saurabh, C.K., Tye Y.Y., Suriani, A.B., Mohamed, A., Karim, A.A., Rizal, S. and Paridah, M.T. (2018). Biodegradable Films for Fruits and Vegetables Packaging Application: Preparation and Properties. Food Engineering Reviews, 10(3), 139-153. https:// doi.org/10.1007/s12393-018-9180-3

Aldana, D.S., Andrade-Ochoa, S., Aguilar, C.N., Contreras-Esquivel, J.C. and Nevárez-Moorillón, G.V. (2015). Antibacterial activity of pectic-based edible films incorporated with Mexican lime essential oil. Food Control, 50, 907-912. https:// doi.org/10.1016/j.foodcont.2014.10.044

Alvarado, S., Sandoval, G., Palos, I., Tellez, S., AguirreLoredo, Y. and Velazquez, G. (2015). The effect of relative humidity on tensile strength and water Vapour permeability in chitosan, fish gelatin and transglutaminase edible films. Food Science and Technology, 35(4), 690-695. https:// doi.org/10.1590/1678-457X.6797

Avena-Bustillos, R.J., Cisneros-Zevallos, L.A., Krochta, J.M. and Saltveit Jr, M.E. (1994). Application of casein-lipid edible film emulsions to reduce white blush on minimally processed carrots. Postharvest Biology and Technology, 4(4), 319-329. https:// doi.org/10.1016/0925-5214(94)90043-4

Axelsson, C. and van Sebille, E. (2017). Prevention through policy: Urban macroplastic leakages to the marine environment during extreme rainfall events. Marine Pollution Bulletin, 124(1), 211-227. https:// doi.org/10.1016/j.marpolbul.2017.07.024

Barth, M., Hankinson, T.R., Zhuang, H. and Breidt, F. (2009). Microbiological spoilage of fruits and vegetables. In Compendium of the microbiological spoilage of foods and beverages, p. 135-183. New York, USA: Springer. https://doi.org/10.1007/978-14419-0826-1_6

Bhandari, B.R. and Roos, Y.H. (2016). (Eds.) Nonequilibrium states and glass transitions in foods: Processing effects and product-specific implications. USA: Woodhead Publishing Series

Błedzki, A.K., Jaszkiewicz, A., Urbaniak, M. and Stankowska-Walczak, D. (2012). Biocomposites in the past and in the future. Fibres Textiles and Eastern European, 96(6), 15-22.

Bourtoom, T., Chinnan, M.S., Jantawat, P. and 
Sanguandeekul, R. (2006). Effect of plasticizer type and concentration on the properties of edible film from water-soluble fish proteins in surimi washwater. Food Science and Technology International, 12(2), 119-126. https:// doi.org/10.1177/1082013206063980

Carrión-Granda, X., Fernández-Pan, I., Rovira, J. and Maté, J.I. (2018). Effect of Antimicrobial Edible Coatings and Modified Atmosphere Packaging on the Microbiological Quality of Cold Stored Hake (Merluccius merluccius) Fillets. Journal of Food Quality, 2018, $6194906 . \quad$ https:// doi.org/10.1155/2018/6194906

Cheba, B.A. (2015). Chitin and Chitosan: Marine Biopolymers with Unique Properties and Versatile Applications. Global Journal of Biotechnology and Biochemistry, 6(3), 149-153.

Chen, G., Zhang, B., Zhao, J. and Chen, H. (2014). Development and characterization of food packaging film from cellulose sulfate. Food Hydrocolloid, 35 (2), 476-483. https://doi.org/10.1016/ j.foodhyd.2013.07.003

Chinma, C.E., Ariahu, C.C. and Abu, J.O. (2012). Development and characterization of cassava starch and soy protein concentrate based edible films. International Journal of Food Science and Technology, 47(2), 383-389. https://doi.org/10.1111/ j.1365-2621.2011.02851.x

Chinma, C.E., Ariahu, C.C. and Alakali, J.S. (2015) Effect of temperature and relative humidity on the water vapour permeability and mechanical properties of cassava starch and soy protein concentrate based edible films. Journal of Food Science and Technology, 52(4), 2380-2386. https:// doi.org/10.1007/s13197-013-1227-0

Coles, R., McDowell, D. and Kirwan, M.J. (2003). Food packaging technology. Boca Raton, Florida, USA: CRC Press LLC.

Conte, A., Scrocco, C., Sinigaglia, M. and Del Nobile, M.A. (2007). Innovative active packaging systems to prolong the shelf life of Mozzarella cheese. Journal of Dairy Science, 90(5), 2126-2131. https:// doi.org/10.3168/jds.2006-709

Day, L. (2011). Wheat gluten: production, properties and application. In Phillips, G.O. and Williams, P.A. (Eds.) Handbook of Food Proteins, p. 267-288. USA: Woodhead Publishing Limited. https:// doi.org/10.1533/9780857093639.267

Di Pierro, P., Sorrentino, A., Mariniello, L., Giosafatto, C.V.L. and Porta, R. (2011). Chitosan/whey protein film as active coating to extend Ricotta cheese shelflife. LWT - Food Science Technology, 44(10), 2324 2327. https://doi.org/10.1016/j.lwt.2010.11.031

Fang, Z., Zhao, Y., Warner, R.D. and Johnson, S.K.
(2017). Active and intelligent packaging in meat industry. Trends Food Science and Technology, 61, 60-71. https://doi.org/10.1016/j.tifs.2017.01.002

Ferrari, C.C., Sarantópoulos, C.I., Carmello-Guerreiro, S.M., and Hubinger, M.D. (2013). Effect of osmotic dehydration and pectin edible coatings on quality and shelf life of fresh-cut melon. Food and Bioprocess Technology, 6(1), 80-91. https:// doi.org/10.1007/s11947-011-0704-6

Garavand, F., Rouhi, M., Razavi, S.H., Cacciotti, I. and Mohammadi, R. (2017). Improving the integrity of natural biopolymer films used in food packaging by crosslinking approach: A review. International Journal of Biological Macromolecules, 104(Part A), 687-707.

https://doi.org/10.1016/

j.ijbiomac.2017.06.093

García-Ochoa, F., Santos, V.E., Casas, J.A. and Gómez, E. (2000). Xanthan gum Production, recovery, and properties. Biotechnology Advanced, 18(7), 549579. https://doi.org/10.1016/S0734-9750(00)00050-1

Gennadios, A., Park, H.J. and Weller, C.L. (1993). Relative Humidity and Temperature Effects on Tensile Strength of Edible Protein and Cellulose Ether Films. Biological System Engineering, 36(6), 1867-1872. https://doi.org/10.13031/2013.28535

Geueke, B., Groh, K. and Muncke, J. (2018). Food packaging in the circular economy: Overview of chemical safety aspects for commonly used materials. Journal of Cleaner Production, 193, 491505. https://doi.org/10.1016/j.jclepro.2018.05.005

Günlü, A. and Koyun, E. (2013). Effects of vacuum packaging and wrapping with chitosan-based edible film on the extension of the shelf life of sea bass (Dicentrarchus labrax) fillets in cold storage $\left(4^{\circ}\right.$ C). Food and Bioprocess Technology, 6(7), 17131719. https://doi.org/10.1007/s11947-012-0833-6

Heralp, T.J., Gnanasambandam, R., McGuire, B.H. and Hachmeister, K.A. (1995). Degradable wheat gluten films: preparation, properties and applications. Journal of Food Science, 60(5), 11471150. https://doi.org/10.1111/j.13652621.1995.tb06311.x

Hosseini, S.F., Rezaei, M., Zandi, M. and Ghavi, F.F. (2013). Preparation and functional properties of fish gelatin-chitosan blend edible films. Food Chemistry, 136(3-4), 1490-1495. https:// doi.org/10.1016/j.foodchem.2012.09.081

Javanmard, M. (2008). Effect of whey protein edible film packaging on the quality and moisture uptake of dried peanuts. Journal of Food Process Engineering, 31(4), 503-516. https://doi.org/10.1111/j.17454530.2007.00165.x

Joseph, C.S., Prashanth, K.H., Rastogi, N.K., Indiramma, A.R., Reddy, S.Y. and Raghavarao, K.S.M.S. 
Ozcalik, O. and Tihminlioglu, F. (2013). Barrier properties of corn zein nanocomposite coated polypropylene films for food packaging applications. Journal of Food Engineering, 114(4), 505-513. https://doi.org/10.1016/j.jfoodeng.2012.09.005

Padrão, J., Gonçalves, S., Silva, J.P., Sencadas, V., Lanceros-Méndez, S and Pinheiro, A.C. (2016). Bacterial cellulose-lactoferrin as an antimicrobial edible packaging. Food Hydrocolloids, 58(8), 126140. https://doi.org/10.1016/j.foodhyd.2016.02.019

Park, H.J. and Chinnan, M.S. (1995). Gas and water Vapour barrier properties of edible films from protein and cellulosic materials. Journal of Food Engineering, 25(4), 497-507. https:// doi.org/10.1016/0260-8774(94)00029-9

Peretto, G., Du, W.X., Avena-Bustillos, R.J., De, J., Berrios, J., Sambo, P. and McHugh, T.H. (2017). Electrostatic and Conventional Spraying of AlginateBased Edible Coating with Natural Antimicrobials for Preserving Fresh Strawberry Quality. Food Bioprocess Technology, 10(1), 165-174. https:// doi.org/10.1007/s11947-016-1808-9

Perez-Gago, M.B. and Krochta, J.M. (2001). Denaturation Time and Temperature Effects on Solubility, Tensile Properties, and Oxygen. Journal of Food Science, 66(5), 705-710. https:// doi.org/10.1111/j.1365-2621.2001.tb04625.x

Picchio, M.L., Linck, Y.G., Monti, G.A., Gugliotta, L.M., Minari, R.J. and Alvarez Igarzabal, C.I.A. (2018). Casein films crosslinked by tannic acid for food packaging applications. Food Hydrocolloids, 84 (11), 424-434. https://doi.org/10.1016/ j.foodhyd.2018.06.028

Prashanth, K.H. and Tharanathan, R.N. (2007). Chitin/ chitosan: modifications and their unlimited application potential - an overview. Trends in Food Science and Technology, 18(3), 117-131. https:// doi.org/10.1016/j.tifs.2006.10.022

Rodriguez-Turienzo, L., Cobos, A. and Diaz, O. (2012). Effects of edible coatings based on ultrasoundtreated whey proteins in quality attributes of frozen Atlantic salmon (Salmo salar). Innovation of Food Science and Emerging Technology, 14, 92-98. https://doi.org/10.1016/j.ifset.2011.12.003

Romani, V.P., Machado, A.V., Olsen, B.D. and Martins, V.G. (2018). Effects of $\mathrm{pH}$ modification in proteins from fish (Whitemouth croaker) and their application in food packaging films. Food Hydrocolloids, 74(1), 307-314.

https://doi.org/10.1016/ j.foodhyd.2017.08.021

Sanyang, M.L., Sapuan, S.M., Jawaid, M., Ishak, M.R. and Sahari, J. (2015). Effect of plasticizer type and concentration on tensile, thermal and barrier properties of biodegradable films based on sugar palm (Arenga pinnata) starch. Polymers, 7(6), 11061124. https://doi.org/10.3390/polym7061106

Saraiva, L.E.F., Naponucena, L.D.O. M., da Silva Santos, V., Silva, R.P.D., de Souza, C.O., Souza, I.E.G.L. and Druzian, J.I. (2016). Development and application of edible film of active potato starch to extend mini panettone shelf life. LWT-Food Science Technology, 73, 311-319. https://doi.org/10.1016/ j.lwt.2016.05.047

Sébastien, F., Stéphane, G., Copinet, A. and Coma, V. (2006). Novel biodegradable films made from chitosan and poly(lactic acid) with antifungal properties against mycotoxinogen strains. Carbohydrates Polymers, 65(2), 185-193. https:// doi.org/10.1016/j.carbpol.2006.01.006

Seol, K.H., Lim, D.G., Jang, A., Jo, C. and Lee, M. (2009). Antimicrobial effect of $\kappa$-carrageenan-based edible film containing ovotransferrin in fresh chicken breast stored at $5^{\circ} \mathrm{C}$. Meat Science, 83(3), 479-483.

https://doi.org/10.1016/ j.meatsci.2009.06.029

Sharma, S. and Rao, T.V.R. (2015). Xanthan gum based edible coating enriched with cinnamic acid prevents browning and extends the shelf-life of fresh-cut pears. LWT - Food Science and Technology, 62(1), 791-800. https://doi.org/10.1016/j.lwt.2014.11.050

Shojaee-Aliabadi, S., Hosseini, H., Mohammadifar, M.A., Mohammadi, A., Ghasemlou, M. and Ojagh, S.M. (2013). Characterization of antioxidantantimicrobial $\kappa$-carrageenan films containing Satureja hortensis essential oil. International Journal of Biological Macromolecules, 52, 116-124. https://doi.org/10.1016/j.ijbiomac.2012.08.026

Shylga, O., Pritulska, N., Petrusha, O. and Smirnova, J. (2018). Edible coatings - environmental replacing of traditional candy paper wrapper of "korivka" candies. Food and Environment Safety Journal, 17 (1), 2559-6381.

Singh, P., Kumar, R., Sabapathy, S.N. and Bawa, A.S. (2008). Functional and edible uses of soy protein products. Comprehensive Review in Food Science and Food Safety, 7(1), 14-28. https:// doi.org/10.1111/j.1541-4337.2007.00025.x

Siracusa, V. (2012). Food Packaging Permeability behavior. (2012). A Report. International Journal of Polymer Science, 2012, 302029. https:// doi.org/10.1155/2012/302029

Siracusa, V., Rocculi, P., Romani, S. and Dalla Rosa, M. (2008). Biodegradable polymers for food packaging: a review. Trends in Food Science and Technology journal, 19(12), 634-643. https://doi.org/10.1016/ j.tifs.2008.07.003

Sogut, E. and Seydim, A.C. (2018). Development of Chitosan and Polycaprolactone based active bilayer 
(2011). Optimum blend of chitosan and poly-( $\varepsilon$ caprolactone) for fabrication of films for food packaging applications. Food and Bioprocess Technology, 4(7), 1179-1185. https:// doi.org/10.1007/s11947-009-0203-1

Kanmani, P. and Rhim, J.W. (2014). Properties and characterization of bionanocomposite films prepared with various biopolymers and $\mathrm{ZnO}$ nanoparticles. Carbohydrates Polymer, 106, 190-199. https:// doi.org/10.1016/j.carbpol.2014.02.007

Karthik, T. and Rathinamoorthy, R. (2018). Sustainable biopolymers in textiles: An overview. In Martinez, L., Kharissova, O. and Kharisov, B. (Eds.) Handbook of Ecomaterials. Cham, Netherlands: Springer International Publishing. https:// doi.org/10.1007/978-3-319-48281-1_53-1

Kim, D.N., Min, B., Lee, S.H. and Lee, S. (2012). Influence of surface coating with xanthan gum on heat transfer during deep-fat frying of potato strips. Journal of Food Process Engineering, 35(6), 898-904. https://doi.org/10.1111/j.17454530.2011.00639.x

Kinsella, J.E. (1979). Functional properties of soy proteins. Journal of the American Oil Chemists Society, 56(3Part1), 242-258. https:// doi.org/10.1007/BF02671468

Kirwan, M.J., Plant, S. and Strawbridge, J.W. (2011). Plastics in Food Packaging. Food Beverage Packaging Technology. 2nd ed. United Kingdom: Wiley Blackwell. doi.org/10.1002/9781444392180.ch7

Layuk, P., Sondakh, J.and Pesireron, M. (2019). Characteristics and Permeability properties of Sago Starch Edible Film. Journal of Agricultural Technology, 8(2), 34-41. https://doi.org/10.30598/ jagritekno.2019.8.2.34

Lee, K.Y. and Mooney, D.J. (2012). Alginate: properties and biomedical applications. Progress in Polymer Science, 37(1), 106-126. https://doi.org/10.1016/ j.progpolymsci.2011.06.003

Lee, S.Y., Lee, S.J., Choi, D.S. and Hur, S.J. (2015). Current topics in active and intelligent food packaging for preservation of fresh foods. Journal of Science of Food and Agriculture, 95(14), 27992810. https://doi.org/10.1002/jsfa.7218

Liang, J., Wang, R. and Chen, R. (2019). The Impact of Cross-linking Mode on the Physical and Antimicrobial Properties of a Chitosan/Bacterial Cellulose Composite. Polymers, 11(3), 491. https:// doi.org/10.3390/polym11030491

Lin, M.G., Lasekan, O., Saari, N. and Khairunniza-Bejo, S. (2018). Effect of edible coatings based on chitosan and carrageenan on longan (Dimocarpus longan) fruits after harvest. Cy-TA Journal of Food,
$16(1)$ 490-497. doi.org/10.1080/19476337.2017.1414078

https://

Ljungberg, N. and Wessle, B. (2005). Preparation and properties of plasticized Poly (lactic acid) Films, Biomacromolecules, 6(3), 1789-1796. https:// doi.org/10.1021/bm050098f

Luecha, J., Sozer, N. and Kokini, J.L. (2010). Synthesis and properties of corn zein/montmorillonite nanocomposite films. Journal of Material Science, 45(13), 3529-3537. https://doi.org/10.1007/s10853010-4395-6

Ma, X., Chang, P.R., Yu, J. and Stumborg, M. (2009). Properties of biodegradable citric acid-modified granular starch/thermoplastic pea starch composites. Carbohydrates Polymers, 75(1), 1-8. https:// doi.org/10.1016/j.carbpol.2008.05.020

Mani, A., Jain, N., Singh, A.K. and Sinha, M. (2017). Effects of aloevera edible coating on quality and postharvest physiology of ber (Zizyphus Mauritiana Lamk.) under ambient storage conditions. International Journal of Pure and Applied Bioscience, 5(6), 43-53. https:// doi.org/10.18782/2320-7051.5688

Marquez, G.R., Di Pierro, P., Mariniello, L., Esposito, M., Giosafatto, C.V. and Porta, R. (2017). Fresh-cut fruit and vegetable coatings by transglutaminasecrosslinked whey protein/pectin edible films. $L W T$ Food Science Technology, 75, 124-130. https:// doi.org/10.1016/j.lwt.2016.08.017

Marsh, K. and Bugusu, B. (2007). Food packagingroles, materials, and environmental issues. Journal of Food Science, 72(3), R39-R55. https:// doi.org/10.1111/j.1750-3841.2007.00301.x

Moreira, M.R., Tomadoni, B., Martín-Belloso, O. and Soliva-Fortuny, R. (2015). Preservation of fresh-cut apple quality attributes by pulsed light in combination with gellan gum-based prebiotic edible coatings. LWT-Food Science and Technology, 64(2), 1130-1137. https://doi.org/10.1016/j.lwt.2015.07.002

Muller, J., González-Martínez, C. and Chiralt, A. (2017). Combination of Poly(lactic) acid and starch for biodegradable food packaging. Materials, 10(8), 952. https://doi.org/10.3390/ma10080952

Nešić, A., Cabrera-Barjas, G., Dimitrijević-Branković, S., Davidović, S., Radovanović, N. and Delattre, C. (2020). Prospect of polysaccharide-based materials as advanced food packaging. Molecules, 25(1), 1-35. https://doi.org/10.3390/molecules25010135

Ortega-Toro, R., Collazo-Bigliardi, S., Roselló, J., Santamarina, P. and Chiralt, A. (2017). Antifungal starch-based edible films containing Aloe vera. Food Hydrocolloids, 72(11), 1-10. https://doi.org/10.1016/ j.foodhyd.2017.05.023 
films enhanced with nanocellulose and grape seed extract. Carbohydrates Polymers, 195, 180-188. https://doi.org/10.1016/j.carbpol.2018.04.071

Soletska, A., Nistor, K. and Hevryk, V. (2018). Edible Film-Forming Coating with $\mathrm{CO}_{2}$-Extracts of Plants For Meat Products, Food Science and Technology, 12(3) 50-56. https://doi.org/10.15673/fst.v12i3.1039

Sothornvit, R. and Krochta, J.M. (2005). Plasticizers in edible films and coatings. In Jung, H.H. (Ed.) Innovations in food packaging, p. 403-433. USA: Academic Press. https://doi.org/10.1016/B978012311632-1/50055-3

Souza, A.C., Benze, R.F.E.S., Ferrão, E.S., Ditchfield, C., Coelho, A.C.V. and Tadini, C.C. (2012). LWTCassava starch biodegradable films: In fluence of glycerol and clay nanoparticles content on tensile and barrier properties and glass transition temperature. LWT-Food Science and Technology, 46 (1), 110-117. https://doi.org/10.1016/ j.lwt.2011.10.018

Suderman, N., Isa, M.I.N. and Sarbon, N.M. (2018). The effect of plasticizers on the functional properties of biodegradable gelatin-based film: A review. Food Bioscience, 24, 111-119. https://doi.org/10.1016/ j.fbio.2018.06.006

Tang, X., Alavi, S. and Herald, T.J. (2008). Barrier and Mechanical Properties of Starch-Clay nanocomposite Films. Cereal chemistry, 85(3), 433439. https://doi.org/10.1094/CCHEM-85-3-0433

Tao, Z., Weng, W.Y., Cao, M.J., Liu, G.M., Su, W.J., Osako, K. and Tanaka, M. (2015). Effect of blend ratio and $\mathrm{pH}$ on the physical properties of edible composite films prepared from silver carp surimi and skin gelatin. Journal of Food Science and Technology, 52(3), 1618-1625. https:// doi.org/10.1007/s13197-013-1186-5

Thawien, W. (2012). Protein based edible films. Characteristics and improvement of properties. In Eissa, A.A. (Ed.) Structure and Function of Food Engineering. InTech Open E-Book.

Valdés, A., Mellinas, A.C., Ramos, M., Garrigós, M.C. and Jiménez, A. (2014). Natural additives and agricultural wastes in biopolymer formulations for food packaging. Frontier in Chemistry, 2, 6. https:// doi.org/10.3389/fchem.2014.00006

Vieira, M.G.A., Da Silva, M.A., Dos Santos, L.O. and Beppu, M.M. (2011). Natural-based plasticizers and biopolymer films: A review. European Polymer Journal, 47(3), 254-263. https://doi.org/10.1016/ j.eurpolymj.2010.12.011

Wei, Y.C., Cheng, C.H., Ho, Y.C., Tsai, M.L. and Mi, F.L. (2017). Active gellan gum/purple sweet potato composite films capable of monitoring $\mathrm{pH}$ variations. Food Hydrocolloids, 69(8), 491-502. https://doi.org/10.1016/j.foodhyd.2017.03.010

Xiao, G., Zhu, Y., Wang, L., You, Q., Huo, P. and You, Y. (2011). Production and Storage of Edible Film using gellan gum. Procedia Environmental Sciences, 8, 756-763. https://doi.org/10.1016/ j.proenv.2011.10.115

Yang, M., Wang, L. and Xia, Y. (2019). Ammonium persulphate induced synthesis of polymethyl methacrylate grafted sodium alginate composite films with high strength for food packaging. International Journal of Biological Macromolecule, 124, 1238-1245. https://doi.org/10.1016/ j.ijbiomac.2018.12.012

Youssef, A.M., Assem, F.M., El-Sayed, S.M., Salama, H. and Abd El-Salam, M.H. (2017). Utilization of edible films and coatings as packaging materials for preservation of cheeses. Journal of Packaging Technology and Research, 1(2), 87-99. https:// doi.org/10.1007/s41783-017-0012-3

Yun, X., Wang, Y., Li, M., Jin, Y., Han, Y. and Dong, T. (1966). Application of permselective $\operatorname{poly}(\varepsilon-$ caprolactone) film for equilibrium-modified atmosphere packaging of strawberry in cold storage. Journal of Food Process and Preservation, 41(6), 110. https://doi.org/10.1111/jfpp.13247

Zakaria, N.H., Muhammad, N., Sandu, A.V. and Abdullah, M.M.A.B. (2018). Effect of Mixing Temperature on characteristics of thermoplastic potato starch film. IOP Conference Series: Materials Science and Engineering, 374(1). https:// doi.org/10.1088/1757-899X/374/1/012083

Zhang, X., Xiao, G., Wang, Y., Zhao, Y., Su, H. and Tan, T. (2017). Preparation of chitosan-TiO2 composite film with efficient antimicrobial activities under visible light for food packaging applications. Carbohydrates Polymer, 169, 101-107. https:// doi.org/10.1016/j.carbpol.2017.03.073

Zhong, Y., Godwin, P., Jin, Y. and Xiao, H (2019). Biodegradable Polymers and Green based Antimicrobial Packaging Materials: A mini-review, Advanced Industrial and Engineering Polymer Research, 3(1), 27-35. https://doi.org/10.1016/ j.aiepr.2019.11.002

Zia, K.M., Tabasum, S., Nasif, M., Sultan, N., Aslam, N., Noreen, A. and Zuber, M. (2017). A review on synthesis, properties and applications of natural polymer based carrageenan blends and composites. International Journal Biologicals Macromolecules, 96, 282-301. https://doi.org/10.1016/ j.ijbiomac.2016.11.095 